\title{
Cu-resistant Kocuria sp. CRB15: a potential PGPR isolated from the dry tailing of Rakha copper mine
}

\author{
Arti Hansda $^{1} \cdot$ Vipin Kumar $^{1} \cdot$ Anshumali $^{1}$
}

Received: 25 July 2016/Accepted: 30 January 2017/Published online: 8 June 2017

(C) Springer-Verlag Berlin Heidelberg 2017

\begin{abstract}
Rhizobacteria may enhance biomass production and heavy metal tolerance of plants under stress conditions. The present study was carried out for isolation of metalresistant bacteria that can be further utilized for phytoremediation process. A potential metal-resistant strain CRB15 was isolated from rhizospheric region of Saccharum spontaneum that was found to be resistant against $\mathrm{Cu}$ (6.29 mM), Zn (3.25 mM), Pb (1.5 mM), Ni (1.25 mM), and $\mathrm{Cd}(0.25 \mathrm{mM})$. SEM analysis was performed for evaluation of morphological changes on bacterial isolate. FTIR analysis observed the change in wavenumbers after the addition of $\mathrm{Cu}$. 16S rDNA sequence analysis showed that CRB15 isolate matched best with genus of Kocuria and was named as Kocuria sp. CRB15. The isolate Kocuria sp. CRB15 was a potential plant growth-promoting rhizobacterium as it had a high IAA $\left(46 \mu \mathrm{g} \mathrm{ml}^{-1}\right), \mathrm{P}$ solubilisation $\left(39.37 \mu \mathrm{g} \mathrm{ml}^{-1}\right), \quad$ ammonia production $\left(30.46 \mu \mathrm{mol} \mathrm{ml}^{-1}\right)$, and hydrogen cyanide production capacity. Root-shoot elongation assay conducted on Brassica nigra under lab conditions with strain CRB15 demonstrated positive effects of strain CRB15 in root and shoot elongation of Cu-treated seedlings. This study proved the Kocuria sp. CRB15 a potential PGPR for bacterialassisted phytoremediation.
\end{abstract}

Vipin Kumar

vipinmicro1@gmail.com

1 Department of Environmental Science and Engineering, Centre of Mining Environment, Indian Institute of Technology (Indian School of Mines), Dhanbad, Jharkhand 826004, India
Keywords Kocuria sp. CRB15 - Indole-3-acetic acid (IAA) - Saccharum spontaneum - Heavy metal resistant . Phosphate solubilisation - Ammonia production - Brassica nigra

\section{Introduction}

Copper $(\mathrm{Cu})$ tailings, produced from mining, smelting, and processing of copper ores, may cause severe destruction to ecosystem including plants, animals, microbes, and human health (Wong 2003). Although, $\mathrm{Cu}$ is an essential micronutrient; however, its elevated level may affect the microbially mediated processes. Therefore, it is essential to remove the $\mathrm{Cu}$ pollution from the environment. Remediation of polluted sites using the conventional techniques, such as physico-chemical extraction, land filling, soil washing, and excavation, is costly with high energy and chemical consumption (Jeyasingh and Philip 2005). An effective biotechnological approach "Bioremediation" has received increasing attention as an alternative to clean up a polluted environment due to its cost-effective and ecofriendly nature (Wu et al. 2006). To have a crucial role in remediation, microorganisms in heavy metal-contaminated environment must first cope up with the heavy metal stress by means of immobilization or transformation (Ma et al. 2011).

Despite the fact that microbial remediation of $\mathrm{Cu}$ has been investigated for many years, there is still considerable interest in the microbe-plant association for heavy metal removal from soil (Taj and Rajkumar 2016; Zaidi et al. 2006). Rhizospheric microbes are considered as important component of phytoremediation technology due to their direct effects to enhanced biomass production and heavy metal tolerance of plants by plant-microbe interaction 
(Glick 2003). Rhizosphere is a complex and dynamic microenvironment for root-microbe association to form unique communities having considerable potential for plant growth promotion (Belimov et al. 2005) and detoxification of hazardous compounds (De Souza et al. 1999). Plant growth-promoting rhizobacteria (PGPR) that solubilize phosphate and synthesize growth-promoting substances (e.g., indole acetic acid, siderophores, ethylene, etc) can be applied in the plant-assisted bioremediation of metal-contaminated soil (Khan et al. 2009).

In the present work, a strain (CRB15) was isolated from rhizospheric region of $\mathrm{Cu}$-tolerant plant, Saccharum spontaneum (commonly known as Kans grass) growing on $\mathrm{Cu}$ tailing. The metal tolerance and plant growth-promoting abilities of the strain were evaluated.

\section{Materials and methods}

\section{Study area and sample collection}

The Rakha copper mine selected for this study is situated in the country's prime copper producing belt known as the Singhbhum Copper Belt (SCB) in East Singhbhum, Jharkhand, India. The predominant $\mathrm{Cu}$ mineral Chalcopyrite is present with other sulphide minerals, such as pyrite, molybdenite, and marcasite in small quantities. The main gangue minerals include quartz, magnetite, and chlorite (Deb and Sarkar 1973). The climate of the study area is humid tropical. Maximum temperature range to $39^{\circ} \mathrm{C}$ and minimum temperature is $10{ }^{\circ} \mathrm{C}$. This area comes under the path of south west (SW) monsoon with average rainfall of about $1400 \mathrm{~mm}$ per annum during July to September.

The tailing pond used for sample collection had been abandoned from 2001. Composite sampling of dry tailing from the rhizospheric region of Saccharum spontaneum was carried out in January, 2014 and was processed to the laboratory in labelled and air-tight polyethylene bags. The sample was sieved through a $<2 \mathrm{~mm}$ sieve for removal of plant debris, stones, and soil animals. Part of the sample was kept moist in dark at $4{ }^{\circ} \mathrm{C}$ for bacterial isolation. The remaining part of the sample was air-dried at ambient temperature, ground in a porcelain mortar, and sieved through $0.2 \mathrm{~mm}$ sieve for chemical analysis.

\section{Analysis of chemical properties}

The $\mathrm{pH}$ and conductivity (1:2.5; w/v; sample-to-water ratio), organic carbon by rapid dichromate oxidation technique (Walkley and Black 1934), available nitrogen by alkaline permanganate method (Subbiah and Asija 1956), available phosphorus (Bray and Kurtz 1945), and available potassium by ammonium acetate extractant method (Jackson 1973) were estimated. Total $\mathrm{Cu}$ concentration of the sample was determined by acid digestion of $150 \mathrm{mg}$ tailing sample in microwave digestion system (ETHOS One) using a mixture of conc. $\mathrm{HNO}_{3}$ (68-70\%, Merck, EMPARTA), HF (48-51\% Merck, EMPARTA), and $\mathrm{HClO}_{4}$ (70\% Merck, EMPARTA) in a ratio of 5:1:1 (v/v/v) (Ho et al. 2013) followed by filtration using Whatman no. 42 filter paper and made up to $50 \mathrm{ml}$ with distilled water. Water extractable (WE) (1:8, w/v; sample-to-water ratio) and exchangeable (EX) (1:8, w/v; sample-to- $1 \mathrm{M} \mathrm{MgCl}_{2}$ ratio) $\mathrm{Cu}$ concentration was also determined. All the samples were analyzed for $\mathrm{Cu}$ concentrations by flame atomic absorption spectrophotometer (FAAS, GBC Avanta 200, Australia) using air-acetylene flame. All samples were analyzed in triplicates. The standard solution of $\mathrm{Cu}$ was prepared using a stock solution of $1000 \mathrm{mg} \mathrm{l}^{-1}$ (Merck) in $1 \% \mathrm{HNO}_{3}$ for calibration.

\section{Total bacterial counts and isolation of copper- resistant bacteria}

Erlenmeyer flaks containing $100 \mathrm{ml}$ of sterile physiological salt solution were supplemented with $1.0 \mathrm{~g}$ of tailing sample and shaken at $180 \mathrm{rpm}$ for $30 \mathrm{~min}$, followed by tenfold serial dilutions and plating over sucrose-minimal salts low-phosphate (SLP) agar (sucrose 1\%; $\left(\mathrm{NH}_{4}\right)_{2} \mathrm{SO}_{4}$ $0.1 \% ; \mathrm{K}_{2} \mathrm{HPO}_{4} 0.05 \% ; \mathrm{MgSO}_{4} 0.05 \% ; \mathrm{NaCl} 0.01 \%$; yeast extract $0.05 \%$; $\mathrm{CaCO}_{3} 0.05 \%$; pH $7.0 \pm 0.2$ ) for determination of total culturable bacteria. SLP agar amended with $0.8 \mathrm{mM}$ of $\mathrm{Cu}$ as $\mathrm{CuSO}_{4} \cdot 5 \mathrm{H}_{2} \mathrm{O}$ was used for determination of copper-resistant bacteria (CRB). After autoclaving, $10 \mathrm{mg}$ fungicidin per litre was supplemented to culture media for inhibition of fungal growth. Plates were incubated at $30 \pm 2.0{ }^{\circ} \mathrm{C}$ for $48 \mathrm{~h}$. Cu-resistant colonies were purified on the same media by streaking three-to-four times and stored at $4{ }^{\circ} \mathrm{C}$.

\section{Identification of CRB15}

The bacterial strain CRB15 was preliminary identified by morphological and biochemical tests using the standard methods mentioned in Bergey's Manual of Determinative Bacteriology (Holt et al. 1994). The bacterial strain CRB15 was further identified using $16 \mathrm{~S}$ rDNA gene sequencing. DNA was isolated from the culture followed by quality evaluation on $0.8 \%$ agarose gel, and a single band of highmolecular weight DNA was observed. Isolated DNA was amplified with universal primers $8 \mathrm{~F}\left(5^{\prime}\right.$-AGAGTTTGATC CTGGCTCAG-3') and 1492R (5'-GGTTACCTTGTTAC GACTT-3') using Veriti ${ }^{\circledR} 99$ well Thermal Cycler (Model No. 9902). The PCR mixture $(25 \mu \mathrm{l})$ contained $15.5 \mu \mathrm{l}$ sterile distilled water, $25 \mathrm{mM} \mathrm{MgCl}_{2}(0.5 \mu \mathrm{l}), 10 \times$ assay buffer $(2 \mu \mathrm{l}), 2.5 \mathrm{mM}$ of dNTPs $(0.5 \mu \mathrm{l}), 2 \mu \mathrm{l}$ each of forward and reverse primers, $2 \mu \mathrm{l}$ of genomic DNA, and 
one unit of Taq DNA polymerase $(0.5 \mu \mathrm{l})$. The following reaction conditions were followed: initial denaturation step of $94{ }^{\circ} \mathrm{C}$ for $3 \mathrm{~min}, 30$ cycles of $30 \mathrm{~s}$ for denaturation at $94{ }^{\circ} \mathrm{C}, 1$ cycle of $30 \mathrm{~s}$ for annealing at $52{ }^{\circ} \mathrm{C}, 1$ cycle of $1 \mathrm{~min}$ for extension at $72{ }^{\circ} \mathrm{C}$, and 1 cycle of $7 \mathrm{~min}$ for final extension and stored at $4{ }^{\circ} \mathrm{C}$ for further analysis. The PCR amplicon was enzymatically purified and further subjected to Sanger Sequencing. Bi-directional DNA sequencing reaction of PCR amplicon was carried out with 704F (5'AGATTTTCCGACGGCAGGTT- $\left.3^{\prime}\right)$ and 907R (5'CCGTCAATTCMTTTRAGTTT- $3^{\prime}$ ) primers using BDT v3.1 Cycle sequencing kit on ABI 3730xl Genetic Analyzer. Approximately $1500 \mathrm{bp}$ of PCR product size was observed. All samples were analyzed in triplicate. Both the negative (distilled water + all PCR components) and positive (a DNA template + all PCR components) controls were included in each run.

The 16S rDNA sequence was further subjected to BLAST program and compared against the GenBank database using NCBI Blast program. Gene sequence homology was tested using BLASTn search program (http://www.ncbi.nlm.nih.gov). Gene sequence obtained was aligned by ClustalW using the MEGA 7.0 software, and a neighbour-joining tree was constructed. The gene sequence was submitted to GenBank for assigning of accession number.

\section{Determination of minimum inhibitory concentration (MIC)}

The MIC or the lowest concentration of metals at which no growth occurred was determined on the agar plates $(\mathrm{He}$ et al. 2010). The isolate, CRB15 was inoculated into SLP agar plates containing different concentrations of $\mathrm{CdSO}_{4}$, $\mathrm{ZnSO}_{4}, \mathrm{NiCl}_{2} \cdot 6 \mathrm{H}_{2} \mathrm{O}$, and $\mathrm{Pb}\left(\mathrm{NO}_{3}\right)_{2}$ (Merck, EMPARTA). The growing colonies at a given concentration were subsequently transferred to the next higher concentration. The plates were incubated at $30 \pm 2.0{ }^{\circ} \mathrm{C}$ for $48 \mathrm{~h}$ and evaluated for minimum inhibitory concentration. The stock solutions of heavy metals were prepared in double distilled water and sterilized by autoclaving at $121{ }^{\circ} \mathrm{C}, 15 \mathrm{psi}$ for 15 min.

\section{Effect of $\mathrm{Cu}$ on bacterial growth}

Effect of $\mathrm{Cu}$ on bacterial growth was studied by varying concentration of $\mathrm{Cu}\left(0-150 \mathrm{mg} \mathrm{l}^{-1}\right)$ supplemented SLP broth. Culture was grown aerobically in $50 \mathrm{ml}$ medium in $100 \mathrm{ml}$ Erlenmeyer flasks at $30{ }^{\circ} \mathrm{C}$ for $24 \mathrm{~h}$. Culture grown in the absence of metal was treated as control. Growth was monitored as a function of biomass by measuring the absorbance at $600 \mathrm{~nm}$ against blank in a UV-Visible spectrophotometer (UV-1800, Shimadzu, Japan).

\section{Scanning electron microscopy (SEM) and energy dispersive X-ray spectroscopy (EDX) analysis}

SEM-EDX was carried out to study the surface characteristics of CRB15. During SEM analysis, the cells in the growth medium containing $0-100 \mathrm{mg} \mathrm{Cu} \mathrm{l^{-1 }}$ were prepared and fixed with $0.25 \%$ glutaraldehyde at $4{ }^{\circ} \mathrm{C}$ overnight, then washed three times with sodium phosphate buffer solution followed by dehydration using a gradient series with ethanol. Samples for SEM analysis were mounted on cover glass and allowed for air drying. The samples were then mounted directly on the specimen metal disc using an adhesive tape. Scanning of samples was carried out at different areas using FE-SEM Supra 55 (Germany). The SEM analysis was carried out under the following analytical conditions: $\mathrm{EHT}=10.00 \mathrm{kV}$, $\mathrm{WD}=2.4 \mathrm{~mm}$, Signal $\mathrm{A}=$ InLens.

\section{FTIR analysis}

FTIR analysis was carried out for determination of functional groups responsible for adhering of $\mathrm{Cu}(\mathrm{II})$ to the cell wall. The analysis was determined using dried samples of CRB15 in different copper concentrations and recorded in $\mathrm{KBr}$ pellets at room temperature using an FTIR spectrometer (PerkinElmer 2000). The sample/ $\mathrm{KBr}$ mass ratio was 1:100 and analyzed in the range of $4000-400 \mathrm{~cm}^{-1}$ with a resolution of $4 \mathrm{~cm}^{-1}$.

\section{Plant growth-promoting characteristics of CRB15}

\section{Characterization of bacterial indole-3-acetic acid (IAA)}

The bacterial strain CRB15 was analyzed for indole-3acetic acid production in the presence and absence of $\mathrm{L}$ tryptophan and determined by colorimetric analysis (Zaidi et al. 2006). Cells grown in nutrient broth medium in the exponential phase were collected by centrifugation at $10,000 \mathrm{rpm}$ for $15 \mathrm{~min}$ at $6^{\circ} \mathrm{C}$, followed by washing with sterile physiological salt solution, and re-centrifugation. An inoculum density of $10^{8}$ colony forming units (cfu) $\mathrm{ml}^{-1}$ was prepared by resuspending pelleted cells in sterile physiological salt solution. Bacterial suspensions $(1 \mathrm{ml})$ were cultured for 5 days in flasks containing $20 \mathrm{ml}$ of sucrose-minimal salts (SMS) medium [sucrose 1\%; $\left(\mathrm{NH}_{4}\right)_{2} \mathrm{SO}_{4} 0.1 \% ; \mathrm{K}_{2} \mathrm{HPO}_{4} 0.2 \% ; \mathrm{MgSO}_{4} 0.05 \% ; \mathrm{NaCl}$ $0.01 \%$; yeast extract $0.05 \%$; $\mathrm{CaCO}_{3} 0.05 \%$; and $\mathrm{pH}$ $7 \pm 0.2]$ supplemented with $0-600 \mu \mathrm{g} \mathrm{ml}^{-1}$ of L-tryptophan. After each $24 \mathrm{~h}$ of incubation, bacterial culture was centrifuged at $9000 \mathrm{~g}$ for $15 \mathrm{~min} .2 \mathrm{ml}$ of supernatant was collected and mixed with $100 \mu \mathrm{l}$ of $10 \mathrm{mM}$ orthophosphoric acid and $4 \mathrm{ml}$ of Salkowski reagent $\left(0.5 \mathrm{M} \mathrm{FeCl}_{3}\right.$ in $35 \% \mathrm{HClO}_{4}$ ) and allowed to stand at room temperature for 
20 min, after which pink colour developed in the cell suspensions (Gordon and Weber 1951). The absorbance of pink colour was read at $530 \mathrm{~nm}$ using UV-Visible spectrophotometer. The IAA concentration in culture was determined using a calibration curve of pure IAA as a standard following the linear regression analysis.

\section{Mineral phosphate solubilizing activity}

To analyze the phosphate solubilizing activity, CRB15 was plated onto Pikovskaya's agar medium (Zaidi et al. 2006) with $0.5 \%$ of tricalcium phosphate as the inorganic phosphate source. The plates were incubated at $28 \pm 2{ }^{\circ} \mathrm{C}$ for $72 \mathrm{~h}$, a clear halo around the bacterial colonies indicating the phosphate solubilisation capacity of the bacterial strains. The quantitative estimation of phosphate solubilisation was carried out on Pikovskaya's broth medium, and the change in $\mathrm{pH}$ was also observed. The amount of phosphate released in the Pikovaskaya's was quantitatively measured using chlorostannous reduced molybdophosphoric acid blue method (Jackson 1973).

\section{Evaluation of the hydrogen cyanide (HCN) production}

The isolate was screened for the production of hydrogen cyanide by adapting the method of Lorck (1948). Briefly, nutrient agar was amended with $4.4 \mathrm{~g}$ glycine $1^{-1}$ and bacteria were streaked on modified agar plate. A Whatman filter paper no. 1 soaked in $2 \%$ sodium carbonate in $0.5 \%$ picric acid solution was placed at the top of the plate. Plates were sealed with parafilm and incubated at $35 \pm 2{ }^{\circ} \mathrm{C}$ for 4 days. Development of orange to red colour indicated $\mathrm{HCN}$ production.

\section{Production of ammonia}

Bacterial isolate CRB15 was tested for ammonia production in peptone water (Cappuccino and Sherman 1992). Freshly grown cultures were inoculated in $10 \mathrm{ml}$ peptone water in each tube and incubated for 24-120 h at $30 \pm 2{ }^{\circ} \mathrm{C}$. Culture supernatant was mixed with Nessler's reagent $(0.5 \mathrm{ml})$, and volume was adjusted by adding ammonia-free distilled water. Development of yellow-tobrown colour was measured at $450 \mathrm{~nm}$ using UV-VIS spectrophotometer. The ammonia concentration in culture was determined using a calibration curve of pure ammonium sulphate as a standard following the linear regression analysis. The analysis was performed in triplicate.

\section{Plant elongation assay on filter paper culture}

Based on the plant growth-promoting (PGP) activities of the bacterial strain CRB15, the isolate was used for the plant elongation assay. The plant elongation activity of the bacteria was determined using the modified protocol of Belimov et al. (2001, 2005). Bacteria were grown on nutrient broth medium for $48 \mathrm{~h}$ at $30 \pm 2{ }^{\circ} \mathrm{C}$ and resuspended in sterile distilled water to adjust cell density of $5 \times 10^{7} \mathrm{CFU} \mathrm{ml}^{-1} .6 \mathrm{~mL}$ of bacterial suspensions with $0.5 \mathrm{mM} \mathrm{Cu}$ (treatment) as $\mathrm{CuSO}_{4} \cdot 5 \mathrm{H}_{2} \mathrm{O}$ was added to glass petri dishes with filter paper. Bacterial suspensions without $\mathrm{Cu}$ were considered as control. Blank tests were performed using sterile distilled water or $\mathrm{Cu}$. The seeds of Brassica nigra were surface-sterilized with a mixture of ethanol and $30 \% \mathrm{H}_{2} \mathrm{O}_{2}$ (1:1) for $20 \mathrm{~min}$ followed by washing with sterile distilled water and aseptically placed on wetted filter paper. Root length and shoot length of seedlings were measured after incubation of closed petri dishes for 7 days at $28{ }^{\circ} \mathrm{C}$ in the dark. The assay was repeated three times with four dishes (with ten seeds per dish) for each treatment.

\section{Quality control and quality assurance}

Analytical grade, chemicals, and culture media were used for PCR and microbiological analyses, and double distilled deionized Millipore water (Milli-Q system, Millipore) was used for preparation of all reagents and calibration standards. Calibrated glassware was used for experimental work. To avoid other microbial contamination, special care was taken to transfer the samples from the sampling site to laboratory.

\section{Statistical analysis}

The experiments were carried out in triplicates. The statistical analyses were conducted to find out mean and standard deviation using MS-Excel 2007 (Microsoft Inc.).

\section{Results and discussion}

\section{Chemical properties of tailing}

The chemical properties of samples are summarized in Table 1. The $\mathrm{pH}$ and electrical conductivity (EC) of the collected samples were 4.14 and $0.29 \mathrm{dS} \mathrm{m}^{-1}$, respectively, with low organic carbon and low available N, P, and $\mathrm{K}$ content. The continuous oxidation of pyrite waste was responsible for acidic nature of tailing (Das and Maiti 2008). Along with total concentration of $\mathrm{Cu}$, water extractable and exchangeable forms of $\mathrm{Cu}$ were also determined. This is because, the total metal concentration does not describe the bioavailable forms of metal. The concentrations of the total $\mathrm{Cu}, \mathrm{WE} \mathrm{Cu}$, and $\mathrm{EX} \mathrm{Cu}$ were $952.83,10.81$, and $14.21 \mathrm{mg} \mathrm{kg}^{-1}$, respectively. 
Table 1 Chemical properties and bacterial count of dry tailing

\begin{tabular}{lccl}
\hline Parameters & Mean $\pm \mathrm{SD}$ & Min-max & Median \\
\hline pH $(1: 2.5)$ & $4.14 \pm 0.05$ & $4.1-4.2$ & 4.13 \\
EC $\left(1: 2.5 ; \mathrm{dS} \mathrm{m}^{-1}\right)$ & $0.29 \pm 0.019$ & $0.281-0.318$ & 0.29 \\
Organic carbon $\left(\mathrm{g} \mathrm{kg}^{-1}\right)$ & $2.07 \pm 0.31$ & $1.8-2.4$ & 2.0 \\
Av. $\mathrm{N}\left(\mathrm{mg} \mathrm{kg}^{-1}\right)$ & $71.97 \pm 6.67$ & $64.98-78.27$ & 72.67 \\
Av. $\mathrm{P}\left(\mathrm{mg} \mathrm{kg}^{-1}\right)$ & $1.37 \pm 0.23$ & $1.12-1.58$ & 1.42 \\
Av. K $\left(\mathrm{mg} \mathrm{kg}^{-1}\right)$ & $33.03 \pm 3.89$ & $29.57-37.24$ & 32.28 \\
WE Cu $\left(\mathrm{mg} \mathrm{kg}^{-1}\right)$ & $10.81 \pm 1.44$ & $9.25-12.11$ & 11.08 \\
EX Cu $\left(\mathrm{mg} \mathrm{kg}^{-1}\right)$ & $14.21 \pm 5.71$ & $7.84-18.88$ & 15.92 \\
Total Cu $\left(\mathrm{mg} \mathrm{kg}^{-1}\right)$ & $952.83 \pm 160.68$ & $948.7-1115.54$ & 794.25 \\
TBC & $138 \pm 21.07$ & $116-158$ & 140 \\
CRBC $^{\mathrm{a}}$ & $23 \pm 4.35$ & $18-26$ & 25 \\
\hline
\end{tabular}

$T B C$ total bacterial counts, $C R B C \mathrm{Cu}$-resistant bacterial counts

${ }^{a}$ Values indicate $\mathrm{CFU} \times 10^{5} \mathrm{~g}^{-1}$

\section{Bacterial isolation}

The average CFUs of total bacterial count (TBC) and $\mathrm{Cu}-$ resistant bacterial count (CRBC) were reported (Table 1). The TBC reported was $138 \times 10^{5}$ CFU g of dry tailing, whereas CRBC was $23 \times 10^{5}$ CFU g of dry tailing. Similar trend between TBC and CRBC was also reported by $\mathrm{He}$ et al. (2010). The 15 morphologically different $\mathrm{Cu}$ (II) resistant bacterial strains were screened for their $\mathrm{Cu}(\mathrm{II})$ tolerance limit. One of the potential strain CRB15 showing a high degree of $\mathrm{Cu}$ resistance was selected for further studies.

\section{Identification of CRB15 isolate}

The morphological, physiological, and biochemical characteristics (Table 2) and comparative analysis of the sequence with already available sequences in NCBI showed that the strain CRB15 was close to the member of genus Kocuria. Phylogenetic tree (Fig. 1) was constructed by neighbour-joining method of MEGA7.0 using 16S rDNA sequences of species belonging to genus Kocuria along with $16 \mathrm{~S}$ rDNA sequence of CRB15. The 16S rDNA gene sequence was submitted to NCBI database under the accession number KX417302.1.

\section{Resistance to heavy metals}

The strain CRB15 was observed for very high degree of resistance against selected heavy metals. MIC values varied from 0.25 to $3.25 \mathrm{mM}$ (Table 3). CRB15 showed resistance against $3.25 \mathrm{mM}$ of $\mathrm{Zn}, 1.5 \mathrm{mM}$ of $\mathrm{Pb}, 1.25 \mathrm{mM}$ of $\mathrm{Ni}$, and $0.25 \mathrm{mM}$ of $\mathrm{Cd}$, respectively. Among the heavy metals, $\mathrm{Zn}$ and $\mathrm{Pb}$ were less toxic, whereas $\mathrm{Cd}$ and $\mathrm{Ni}$ were highly toxic to strain CRB15. The order of resistance of
Table 2 Morphological, biochemical, and physiological characterization of CRB15

\begin{tabular}{lll}
\hline Morphology & Traits \\
\hline Gram reaction & + & \\
Shape & Cocci \\
Colour & Pink and translucent \\
\hline Biochemical tests & Traits \\
\hline Catalase & + \\
Indole production & - \\
Methyl red test & - \\
Voges-proskauer test & - \\
Citrate utilization & - \\
Nitrate reduction & + \\
Mannitol & + \\
Motility & - \\
Lactose fermentation & - \\
Sucrose & - \\
Dextrose & + \\
$\mathrm{H}_{2} \mathrm{~S}$ production & + \\
Gas production & + \\
Cellulase activity & + \\
Starch hydrolysis & + \\
\hline Physiological tests & + \\
\hline Growth at $4{ }^{\circ} \mathrm{C}$ & + \\
Growth at $41^{\circ} \mathrm{C}$ & + \\
Growth at $7 \%$ NaCl & \\
\hline & & + \\
\hline
\end{tabular}

CRB15 was $\mathrm{Zn}>\mathrm{Pb}>\mathrm{Ni}>\mathrm{Cd}$. Growth rates of the strain CRB15 in the presence of heavy metals were consistently slower than that of control. Similar results were reported by Suresh Kumar et al. (2001), Pal et al. (2004) and Raja et al. (2006).

\section{Effect of $\mathrm{Cu}$ on bacterial growth}

Effect of $\mathrm{Cu}(\mathrm{II})$ on Kocuria sp. CRB15 was carried out on SLP broth media amended with $0-150 \mathrm{mg} / \mathrm{l}$ of $\mathrm{Cu}(\mathrm{II})$ as $\mathrm{CuSO}_{4} \cdot 5 \mathrm{H}_{2} \mathrm{O}$. The optical density measurements of the cultures incubated for $24 \mathrm{~h}$ were in good agreement according to bacterial resistance for $\mathrm{Cu}$ (II). In general, the growth rate of the strain $\mathrm{CRB} 15$ in the presence of $\mathrm{Cu}(\mathrm{II})$ was consistently slower than the control (Fig. 2). The inability to grow at higher concentration was associated with reduction in growth due to the metal binding capacity of CRB15 which resulted by means of interaction between metal cations and functional groups of the cell wall. Similar results were also reported by Friis and Myers-Keith (1986) and Raja et al. (2006). 


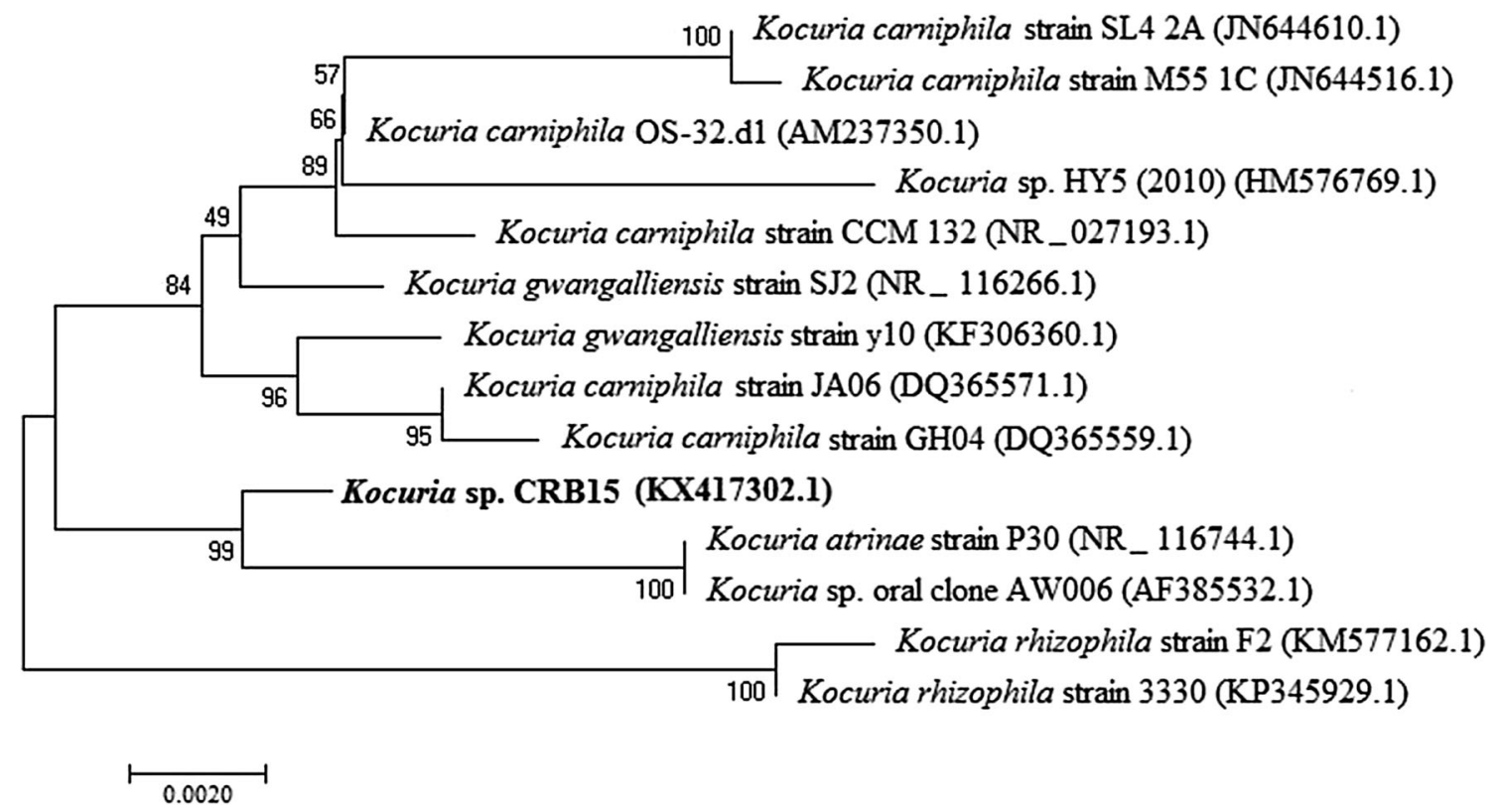

Fig. 1 Phylogenetic neighbour-joining tree based on 16S rDNA gene sequences showing the relationship between Kocuria sp. CRB15 and related members of the genus Kocuria. Bootstrap numbers indicated

Table 3 Minimum inhibitory concentration of heavy metal tolerance of Kocuria sp. CRB15

\begin{tabular}{lllll}
\hline $\mathrm{MIC}(\mathrm{mM})$ & & & & \\
\hline $\mathrm{Cu}$ & $\mathrm{Zn}$ & $\mathrm{Pb}$ & $\mathrm{Cd}$ & $\mathrm{Ni}$ \\
\hline 6.29 & 3.25 & 1.5 & 0.25 & 1.25 \\
\hline
\end{tabular}

\section{SEM-EDX analysis}

The SEM results revealed that depending on the $\mathrm{Cu}(\mathrm{II})$ concentration cell surface morphology changed to some extent due to the extracellular adsorption (Ye et al. 2013). Clear impressions (shown by arrows in Fig. 3c) were easily visualized on the cell surface of bacterial biomass at higher $\mathrm{Cu}^{2+}$ concentration, which may lead towards rupturing or deformation of cells (Fig. 3). Furthermore, the EDX spectra showed that some copper peaks could be detected on the cell surface of treated biomass.

\section{FTIR analysis}

FTIR study was carried out for identification of functional groups involved in adsorption of $\mathrm{Cu}^{2+}$. The FTIR analysis of living cells was shown in Fig. 4 displaying a number of adsorption peaks indicating the complex nature of the biomass examined. The IR spectrum of metal-free and metal loaded biomass showed difference in the functional groups of $-\mathrm{NH},-\mathrm{CH},-\mathrm{CO},-\mathrm{CH}_{2},-\mathrm{PO}$, the value of 500 replicates. Bar represents $0.2 \%$ sequence variation. GenBank accession numbers are given in parentheses

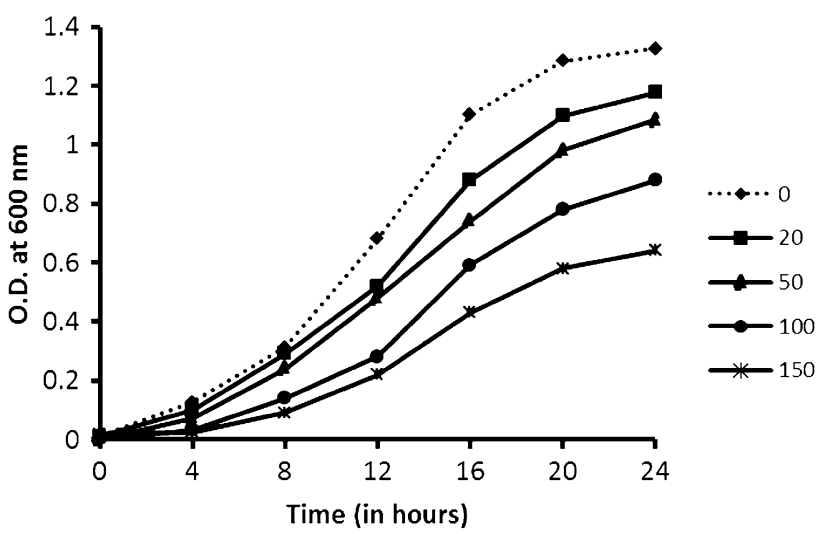

Fig. 2 Growth of CRB15 at $30 \pm 2{ }^{\circ} \mathrm{C}$ with different concentration of $\mathrm{Cu}\left(0-150 \mathrm{mg}^{-1}\right)$ in SLP broth

$-\mathrm{CN},-\mathrm{H}$, and $-\mathrm{COOH}$ by shifting in their peaks (Table 4). These observations validated the involvement of these functional groups in the adsorption process. Due to the presence of $\mathrm{Cu}^{2+}$ in copper-loaded biomass, the peak transmittance and degree of bond stretching became lower than the unloaded biomass. Numerous workers have also reported similar results (Tunali et al. 2006; Giotta et al. 2011). The FTIR spectra of $\mathrm{Cu}$ free and $\mathrm{Cu}$ loaded biomass revealed a complex and additive influence of chemical structure of bacterial cell surface comprising different functional responsible for regulating the possible cell-cation interactions (Anand et al. 2006). 

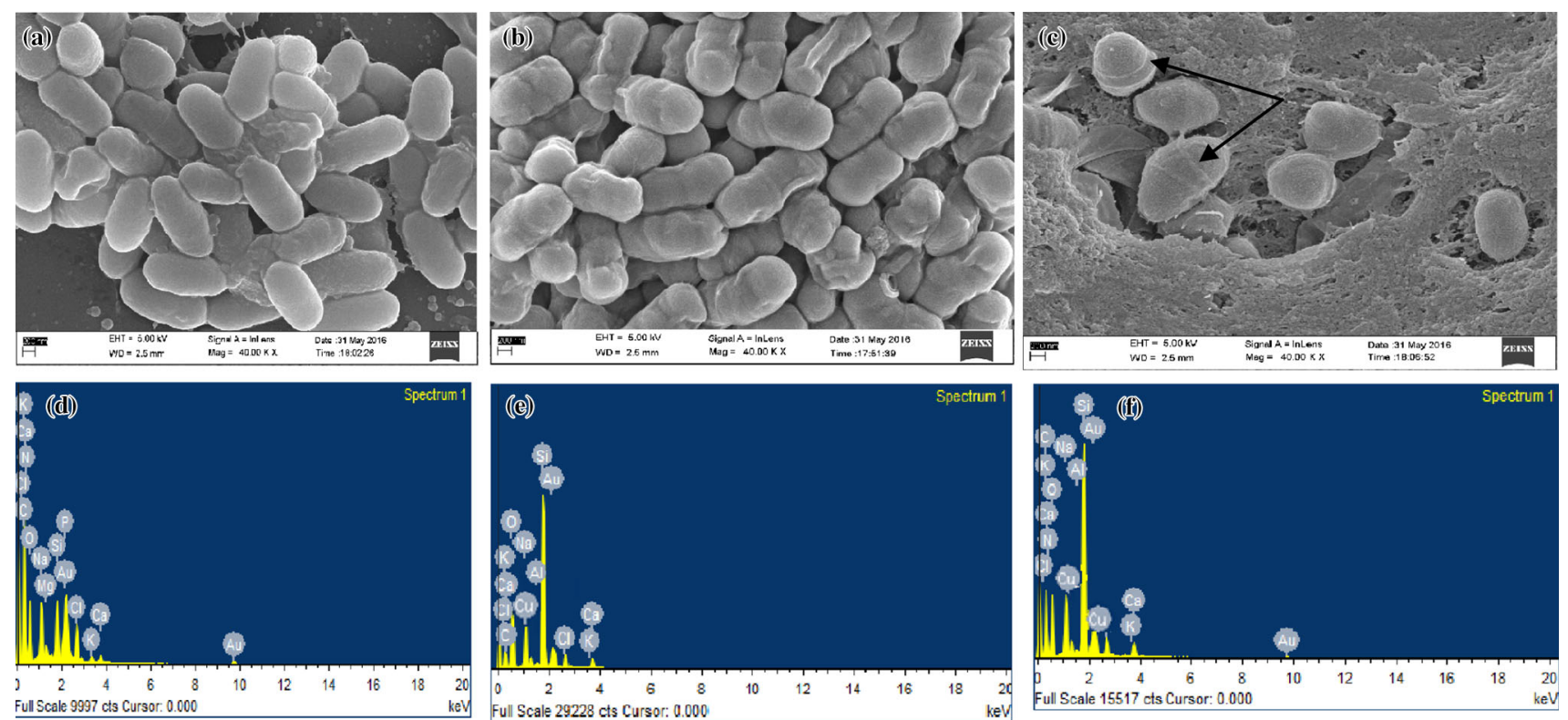

Fig. 3 SEM micrographs of before (a) and after copper-loaded (b $50 \mathrm{mg} \mathrm{L}^{-1}$ and $\mathbf{c} 100 \mathrm{mg} \mathrm{L}^{-1}$ ) of cell surface and corresponding typical EDX spectra (d control, e $50 \mathrm{mg} \mathrm{L}^{-1}$ copper-loaded, and $\mathbf{f} 100 \mathrm{mg} \mathrm{L}^{-1}$ copper-loaded)

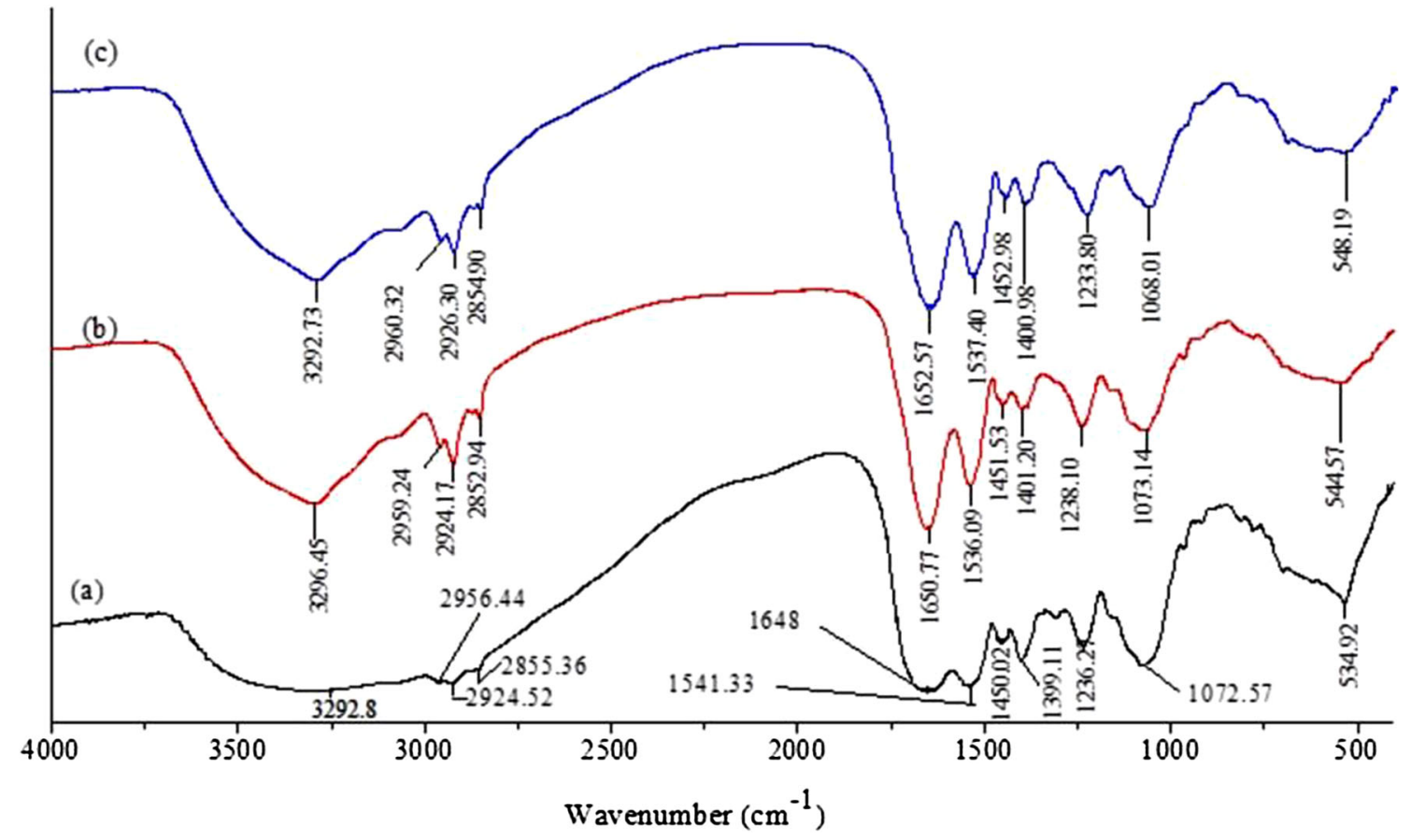

Fig. 4 FTIR spectra of $a$ CRB15 (no copper), $b$ CRB15 $+50 \mathrm{mg} \mathrm{Cu}^{-1}$ and $c$ CRB15 $+100 \mathrm{mg} \mathrm{Cu}^{-1}$

\section{Plant growth-promoting characteristics of CRB15}

\section{Characterization of IAA}

The results showed that IAA production was directly proportional to L-tryptophan. Maximum IAA production of
$46 \mu \mathrm{g} \mathrm{ml}^{-1}$ was observed after $96 \mathrm{~h}$ at $600 \mu \mathrm{g} \mathrm{ml} \mathrm{g}^{-1}$ L-tryptophan concentrations (Fig. 5). Similar trend of IAA production was also reported by Barazani and Friedman (2000). Increase in IAA was observed until $96 \mathrm{~h}$ of incubation, and thereafter, it reached plateau. $5 \mu \mathrm{g} \mathrm{ml}^{-1}$ of IAA was produced in growth medium without L- 
Table 4 Change of IR absorption band in treatments of metals and the possibly corresponding groups

\begin{tabular}{lrrl}
\hline $\begin{array}{l}\text { Original main band } \\
\text { wave numbers }\left(\mathrm{cm}^{-1}\right)\end{array}$ & \multicolumn{2}{l}{$\begin{array}{l}\text { Changed main band } \\
\text { wave numbers }\left(\mathrm{cm}^{-1}\right)\end{array}$} & \\
\cline { 2 - 3 } & $50 \mathrm{ppm}$ & $100 \mathrm{ppm}$ & \\
\hline 3292.8 & 3296.45 & 3292.73 & $-\mathrm{NH}$ \\
2956.44 & 2959.24 & 2960.32 & $-\mathrm{CH}$ \\
2924.52 & 2924.17 & 2926.30 & $-\mathrm{CH}$ \\
2855.36 & 2852.94 & 2854.90 & $-\mathrm{CH}{ }_{2}$ \\
1648.0 & 1650.77 & 1652.57 & $-\mathrm{C}=\mathrm{O}$ \\
1541.33 & 1536.09 & 1537.40 & $-\mathrm{COO},-\mathrm{NH},-\mathrm{CH}$ \\
1450.02 & 1451.53 & 1452.98 & $-\mathrm{CH}{ }_{2}$ \\
1399.11 & 1401.20 & 1400.98 & $-\mathrm{H}$ \\
1236.27 & 1238.10 & 1233.80 & $-\mathrm{COOH},-\mathrm{PO}$ \\
1072.57 & 1073.14 & 1068.01 & $-\mathrm{CO},-\mathrm{CN},-\mathrm{PO}$ \\
534.92 & 544.57 & 548.19 & - \\
\hline
\end{tabular}

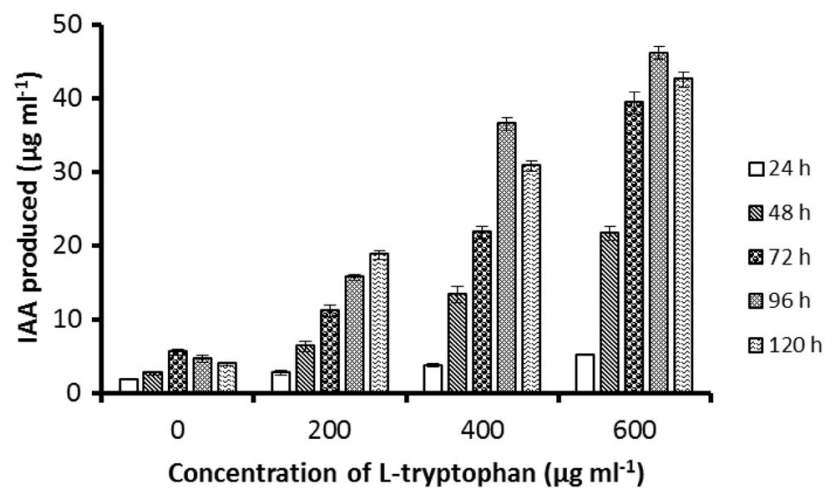

Fig. 5 Correlation between IAA production by Kocuria sp. CRB15 after incubation $(24-120 \mathrm{~h})$ in different concentrations of $\mathrm{L}$ tryptophan

tryptophan. Similar results were also reported for copperresistant bacteria Bacillus sp. BC21 and Arthrobacter sp. MT16 (He et al. 2010). The present study reveals that Kocuria sp. CRB15 is a potential producer of IAA than other PGPR, such as Azotobacter $\left(20 \mu \mathrm{g} \mathrm{ml}^{-1}\right)$, Pseudomonas $\left(25 \mu \mathrm{g} \mathrm{ml}^{-1}\right)$, and Bacillus $\left(10 \mu \mathrm{g} \mathrm{ml}^{-1}\right)$ (Ahmad et al. 2008). Some other members of genus Kocuria, such as $K$. rosea (Godinho et al. 2010), Kocuria sp. PWN-228 (Vicene et al. 2012), and K. turfanensis 2M4 (Goswami et al. 2014), have been also reported as potential producer of IAA.

\section{Phosphate solubilizing activities}

The major mechanism associated with the solubilization of insoluble phosphate is the organic acid production,

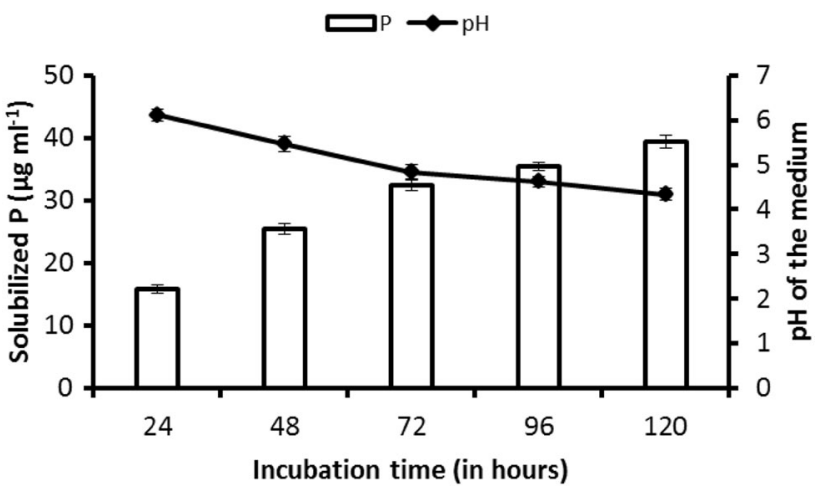

Fig. 6 Phosphate solubilisation and drop in $\mathrm{pH}$ due to acid production by Kocuria sp. CRB15 in various incubation times $(24-120$ h)

accompanied by acidification of the medium (Puente et al. 2004). The present study represents that a gradual increase in solubilized phosphate concentration was observed from 24 to $120 \mathrm{~h}$. Phosphate concentration varied from 15.78 to $39.37 \mu \mathrm{g} \mathrm{ml}^{-1}$ in the culture filtrates of CRB15. A gradual decrease in $\mathrm{pH}$ values from 7.0 to 4.33 was also recorded (Fig. 6). The inverse relationship between $\mathrm{pH}$ and soluble phosphorus concentration observed in the present study suggested that acidification of the medium could facilitate the inorganic phosphate solubilization. The present results were also in agreement with other researchers (Illmer and Schinner 1992; Yu et al. 2011), who reported similar negative relationships. It has been suggested that microorganisms which tend to decrease the $\mathrm{pH}$ of the medium during growth are efficient P-solubilizers.

\section{HCN production}

A colour change was observed in CRB15 indicating its HCN production ability (Fig. 7). Siddiqui et al. (2006) and Akhtar and Siddiqui (2009) reported that HCN is a volatile, secondary metabolite that suppresses the growth of pathogen due to inhibition of metal enzymes, especially cytochrome $C$ oxidases in an electron transport system.

\section{Ammonia production}

It was observed that CRB 15 isolate has produced ammonia in peptone water. Maximum ammonia production of $30.46 \mu \mathrm{mol} \mathrm{ml}{ }^{-1}$ was reported after $96 \mathrm{~h}$ of incubation at $30 \pm 2{ }^{\circ} \mathrm{C}$ (Fig. 8). Ammonia production by Kocuria species were also reported by Goswami et al. (2014).

\section{Root and shoot length promotion}

The effects of the Cu-resistant bacterial strain on root and shoot elongation of B. nigra in the absence or presence of 
Fig. 7 Plates showing $\mathrm{HCN}$ production by a control-no bacteria and b Kocuria sp. CRB15
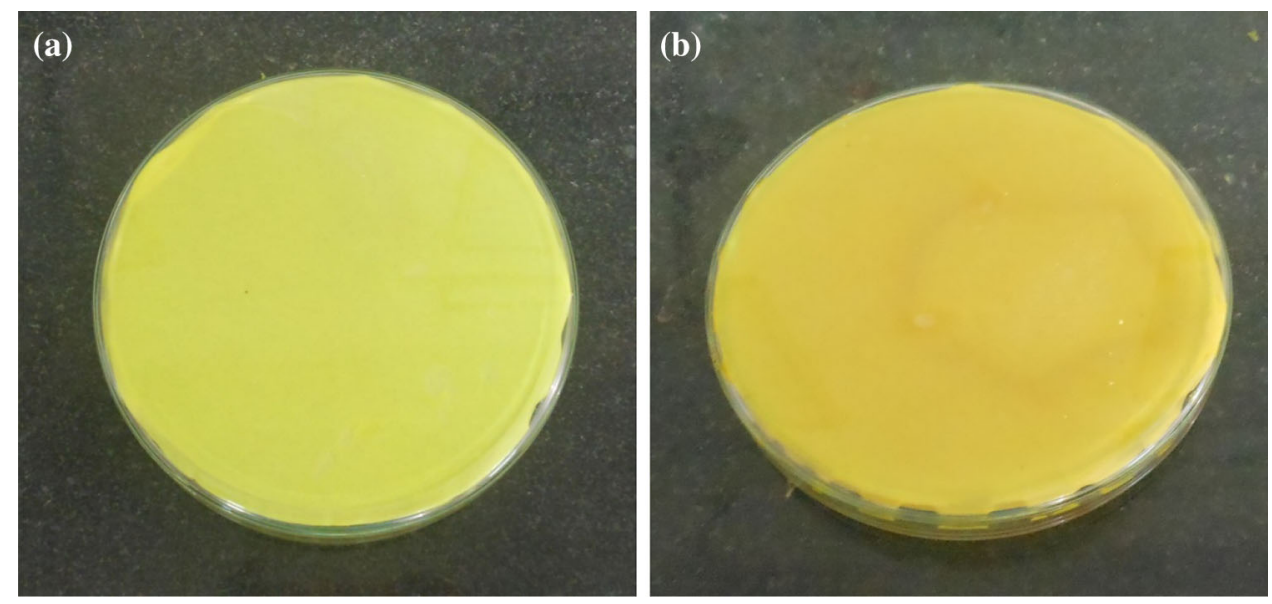

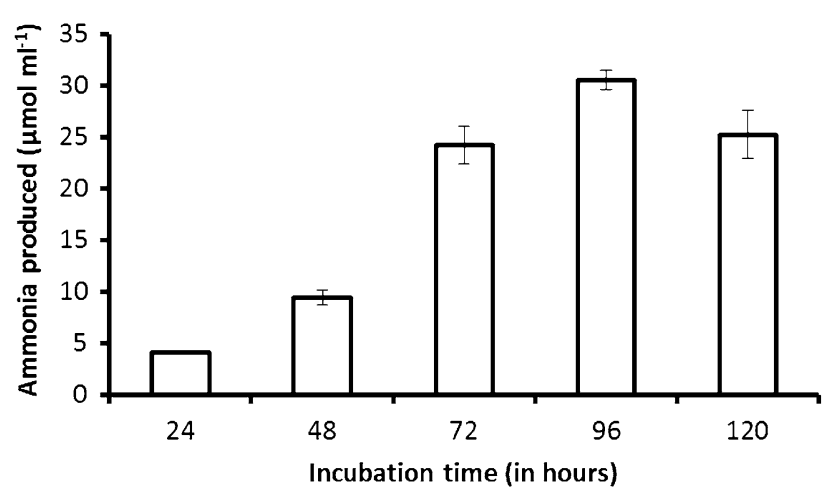

Fig. 8 Ammonia production by Kocuria sp. CRB15 in various incubation times $(24-120 \mathrm{~h})$

$\mathrm{Cu}$ are shown in Table 5. The tested strain increased the root length and shoot length of the seedlings in the absence of $\mathrm{Cu}$. Inoculation with strain CRB15 resulted in increased root length of $\mathrm{Cu}$-treated and $\mathrm{Cu}$-untreated seedlings by 20 and $19 \%$, respectively. Similarly, increased shoot length was also observed for $\mathrm{Cu}$-treated and $\mathrm{Cu}$-untreated seedlings by 39 and $37 \%$, respectively. The maximum root length and shoot length promoting effect was observed after inoculation with strain CRB15 only. Bacteria having the characteristics of producing IAA, inorganic phosphate solubilisation, HCN production, and ammonia production may have the potential for the plant growth promotion and heavy metal resistance, as shown in the root-shoot elongation assay, in which the metal-resistant bacterial strain (CRB15) facilitated $B$. nigra growth even under $\mathrm{Cu}$ concentration (Table 5) (Zaidi et al. 2006). Similar results were also reported by $\mathrm{He}$ et al. (2010) for Brassica napus variety Qinyou-7 seedlings.

\section{Conclusion}

In this study, Kocuria sp. CRB15 isolated from abandoned $\mathrm{Cu}$ tailing was evaluated for its heavy metal resistance and plant growth-promoting activities. These activities may allow the use of isolate for plant growth promotion and bacteria-assisted phytoremediation of $\mathrm{Cu}, \mathrm{Cd}, \mathrm{Ni}, \mathrm{Zn}$, and $\mathrm{Pb}$. SEM-EDX and FTIR analysis evaluated that bacterial cell wall and its functional groups played an important role in metal tolerance. Filter paper assay for root-shoot elongation demonstrated that inoculation with CRB15 lessens the toxic effect of $\mathrm{Cu}$. Future work, such as pot scale study, may be conducted for better understanding and evaluation of effects of Kocuria sp. CRB15 on plant growth and phytoremediation efficiency.

Table 5 Root-shoot length elongation of Brassica nigra seedlings inoculated with copper-resistant bacteria grown in the absence and presence of $\mathrm{Cu}$

\begin{tabular}{lllll}
\hline Treatment & Root length (in cm) & Bacterial effect (\%) & Shoot length (in cm) & Bacterial effect (\%) \\
\hline Distilled water & $4.41(3.94-4.9)$ & - & $6.43(5.9-7.2)$ & - \\
CRB15 & $5.30(4.8-5.9)$ & +20 & $8.96(8.6-9.4)$ & +39 \\
$0.5 \mathrm{mM} \mathrm{Cu}$ & $4.06(3.8-4.5)$ & - & $5.73(4.9-6.4)$ & - \\
CRB15 + 0.5 mM Cu & $4.86(4.6-5.1)$ & +19 & $7.96(7.6-8.5)$ & +37 \\
\hline
\end{tabular}

Values in parentheses indicate range 
Acknowledgements The authors would like to thank the Ministry of Human Resource Development, Government of India and Indian Institute of Technology (Indian School of Mines), Dhanbad for funding the Ph.D. work of Ms. Arti Hansda (Registration no. 2013DR0263). The authors are grateful to the Department of Environmental Science and Engineering, IIT (ISM) Dhanbad for providing the research facilities.

\section{References}

Ahmad F, Ahmad I, Khan MS (2008) Screening of free-living rhizospheric bacteria for their multiple plant growth promoting activities. Microbiol Res 163(2):173-181

Akhtar MS, Siddiqui ZA (2009) Use of plant growth-promoting rhizobacteria for the biocontrol of root-rot disease complex of chickpea. Australas Plant Pathol 38(1):44-50

Anand P, Isar J, Saran S, Saxena RK (2006) Bioaccumulation of copper by Trichoderma viride. Bioresour Technol 97(8):1018-1025

Barazani O, Friedman J (2000) Effect of exogeneously applied Ltryptophan on allelochemical activity of plant growth promoting rhizobacteria (PGPR). J Chem Ecol 26:343-349

Belimov AA, Safronova VI, Sergeyeva TA, Egorova TN, Matveyeva VA, Tsyganov VE, Borisov AY, Tikhonovich IA, Kluge C, Preisfeld A, Dietz KJ, Stepanok VV (2001) Characterization of plant-growth promoting rhizobacteria isolated from polluted soils and containing 1-aminocyclopropane-1-carboxylate deaminase. Can J Microbiol 47:642-652

Belimov AA, Hontzeas N, Safronova VI, Demchinskaya SV, Piluzza G, Bullitta S, Glick BR (2005) Cadmium-tolerant plant growthpromoting bacteria associated with the roots of Indian mustard (Brassica juncea L. Czern.). Soil Biol Biochem 37(2):241-250

Bray RH, Kurtz LT (1945) Determination of total, organic, and available forms of phosphorus in soils. Soil Sci 59(1):39-46

Cappuccino JC, Sherman N (1992) Negative staining. Microbiol Lab Man 3:125-179

Das M, Maiti SK (2008) Comparison between availability of heavy metals in dry and wetland tailing of an abandoned copper tailing pond. Environ Monitor Assess 137(1-3):343-350

De Souza MP, Huang CPA, Chee N, Terry N (1999) Rhizosphere bacteria enhance the accumulation of selenium and mercury in wetland plants. Planta 209(2):259-263

Deb M, Sarkar SC (1973) Sulphide ore bodies and their relation to structure at Roam-Rakha mines-Tamapahar sections, Singhbhum copper belt, Bihar. Recent Res Geol 2:247-264

Friis N, Myers-Keith P (1986) Biosorption of uranium and lead by Streptomyces longwoodensis. Biotechnol Bioeng 28(1):21-28

Giotta L, Mastrogiacomo D, Italiano F, Milano F, Agostiano A, Nagy K, Valli L, Trotta M (2011) Reversible binding of metal ions onto bacterial layers revealed by protonation-induced ATR-FTIR difference spectroscopy. Langmuir 27:3762-3773

Glick BR (2003) Phytoremediation: synergistic use of plants and bacteria to clean up the environment. Biotechnol Adv 21(5):383-393

Godinho A, Ramesh R, Bhosle S (2010) Bacteria from sand dunes of Goa promoting growth in eggplant. World J Agric Sci 6:555-564

Gordon SA, Weber RP (1951) Colorimetric estimation of indoleacetic acid. Plant Physiol 26(1):192

Goswami D, Dhandhukia P, Patel P, Thakker JN (2014) Screening of PGPR from saline desert of Kutch: growth promotion in Arachis hypogea by Bacillus licheniformis A2. Microbiol Res 169(1):66-75

He LY, Zhang YF, Ma HY, Chen ZJ, Wang QY, Qian M, Sheng XF (2010) Characterization of copper-resistant bacteria and assessment of bacterial communities in rhizosphere soils of copper-tolerant plants. Appl Soil Ecol 44(1):49-55

Ho CP, Hseu ZY, Chen NC, Tsai CC (2013) Evaluating heavy metal concentration of plants on a serpentine site for phytoremediation applications. Environ Earth Sci 70:191-199

Holt JG, Krieg NR, Sneath PHA, Staley JT, Williams ST (1994) Bergey's manual of determinative bacteriology, 9th edn. Williams \& Wilkins, Baltimore

Illmer P, Schinner F (1992) Solubilization of inorganic phosphates by microorganisms isolated from forest soils. Soil Biol Biochem 24:389-395

Jackson ML (1973) Soil chemical analysis. Prentice Hall Pvt. Ltd, New Delhi

Jeyasingh J, Philip L (2005) Bioremediation of chromium contaminated soil: optimization of operating parameters under laboratory conditions. J Hazard Mater 118(1):113-120

Khan MS, Zaidi A, Wani PA, Oves M (2009) Role of plant growth promoting rhizobacteria in the remediation of metal contaminated soils. Environ Chem Lett 7(1):1-19

Lorck H (1948) Production of hydrocyanic acid by bacteria. Physiol Plant 1(2):142-146

Ma Y, Prasad MNV, Rajkumar M, Freitas H (2011) Plant growth promoting rhizobacteria and endophytes accelerate phytoremediation of metalliferous soils. Biotechnol Adv 29(2):248-258

Pal A, Choudhuri P, Dutta S, Mukherjee PK, Paul AK (2004) Isolation and characterization of nickel-resistant microflora from serpentine soils of Andaman. World J Microbiol Biotechnol 20(9):881-886

Puente ME, Bashan Y, Li CY, Lebsky VK (2004) Microbial populations and activities in the rhizoplane of rock-weathering desert plants. I. Root colonization and weathering of igneous rocks. Plant Biol 6:629-642

Raja CE, Anbazhagan K, Selvam GS (2006) Isolation and characterization of a metal-resistant Pseudomonas aeruginosa strain. World J Microbiol Biotechnol 22(6):577-585

Siddiqui IA, Shaukat SS, Sheikh IH, Khan A (2006) Role of cyanide production by Pseudomonas fluorescens CHA0 in the suppression of root-knot nematode, Meloidogyne javanica in tomato. World J Microbiol Biotechnol 22(6):641-650

Subbiah BV, Asija GL (1956) A rapid procedure for the determination of available nitrogen in soil. Curr Sci 25:259-260

Suresh Kumar MK, Krishnan HH, Selvam GS (2001) Cadmium resistant bacteria Pseudomonas aeruginosa species isolated from Cochin environment. In: Iyer CSP (ed) Emerging trends in environmental science, 1st edn. Asiatech Publishers Inc., New Delhi, pp 298-304 (ISBN 81-87680-05-9)

Taj ZZ, Rajkumar M (2016) Perspectives of plant growth-promoting actinomycetes in heavy metal phytoremediation. Plant growth promoting actinobacteria. Springer, Singapore, pp 213-231

Tunali S, Cabuk A, Akar T (2006) Removal of lead and copper ion from aqueous solutions by bacterial strain isolated from soil. Chem Eng J 115:203-211

Vicene CS, Nascimento F, Espada M, Barbosa P, Mota M, Glick BR, Oliveira S (2012) Characterization of bacteria associated with pinewood nematode Bursaphelenchus xylophilus. PLoS One 7:e46661

Walkley A, Black IA (1934) An examination of the Degtjareff method for determining soil organic matter and a proposed modification of the chromic acid titration method. Soil Sci $37: 29-38$

Wong MH (2003) Ecological restoration of mine degraded soils, with emphasis on metal contaminated soils. Chemosphere 50(6):775-780

Wu CH, Wood TK, Mulchandani A, Chen W (2006) Engineering plant-microbe symbiosis for rhizoremediation of heavy metals. Appl Environ Microbiol 72(2):1129-1134 
Ye J, Yin H, Xie D, Peng H, Huang J, Liang W (2013) Copper biosorption and ions release by Stenotrophomonas maltophilia in the presence of benzo [a] pyrene. Chem Eng J 219:1-9

Yu X, Liu X, Zhu TH, Liu GH, Mao C (2011) Isolation and characterization of phosphate-solubilizing bacteria from walnut and their effect on growth and phosphorus mobilization. Biol Fertil Soils 47(4):437-446
Zaidi S, Usmani S, Singh BR, Musarrat J (2006) Significance of Bacillus subtilis strain SJ-101 as a bioinoculant for concurrent plant growth promotion and nickel accumulation in Brassica juncea. Chemosphere 64(6):991-997 